\title{
Clostridium Cluster XVI
}

National Cancer Institute

\section{Source}

National Cancer Institute. Clostridium Cluster XVI. NCI Thesaurus. Code C129414.

A group that includes Clostridium innocuum, Eubacterium biforme and Streptococcus pleomorphus, which are within the mycoplasma supercluster. This grouping is based on comparative sequence analysis of their $16 \mathrm{~S}$ ribosomal RNA gene sequences. Some of these species are commensal in humans. 